\title{
Dual role of the caspase enzymes in satellite cells from aged and young subjects
}

\author{
S Fulle ${ }^{1,2,3}$, S Sancilio ${ }^{2,4}$, R Mancinelli ${ }^{1,2,3}$, V Gatta ${ }^{5,6}$ and R Di Pietro ${ }^{*, 2,7}$
}

Satellite cell (SC) proliferation and differentiation have critical roles in skeletal muscle recovery after injury and adaptation in response to hypertrophic stimuli. Normal ageing hinders SC proliferation and differentiation, and is associated with increased expression of a number of pro-apoptotic factors in skeletal muscle. In light of previous studies that have demonstrated agerelated altered expression of genes involved in SC antioxidant and repair activity, this investigation was aimed at evaluating the incidence of apoptotic features in human SCs. Primary cells were obtained from vastus lateralis of nine young (27.3 \pm 2.0 years old) and nine old (71.1 \pm 1.8 years old) subjects, and cultured in complete medium for analyses at 4, 24, 48, and $72 \mathrm{~h}$. Apoptosis was assessed using AnnexinV/propidium iodide staining, the terminal deoxynucleotidyl transferase dUTP nick-end labelling technique, RT-PCR, DNA microarrays, flow cytometry, and immunofluorescence analysis. There was an increased rate of apoptotic cells in aged subjects at all of the experimental time points, with no direct correlation between AnnexinV-positive cells and caspase-8 activity. On the other hand, CASP2, CASP6, CASP7, and CASP9 and a number of cell death genes were upregulated in the aged SCs. Altogether, our data show age-related enhanced susceptibility of human SCs to apoptosis, which might be responsible for their reduced response to muscle damage.

Cell Death and Disease (2013) 4, e955; doi:10.1038/cddis.2013.472; published online 12 December 2013

Subject Category: Experimental Medicine

Ageing is characterised by impairment of muscle-regenerative potential and progressive loss of skeletal muscle., ${ }^{1,2}$ This condition is known as sarcopenia, and it has important healthcare implications for humans, as it can contribute to frailty, functional loss, and premature death. ${ }^{3}$ The ability of skeletal muscle to regenerate is through a population of myogenic stem cells known as satellite cells (SCs). These adult stem cells are located between the sarcolemma and the basal lamina of the muscle fibres, and they constitute $2-4 \%$ of the nuclei in adult skeletal muscle. ${ }^{4-6}$

SCs are typically quiescent in adult muscle. Following physiological stimuli, such as physical activity or muscle injury, SCs are stimulated to proliferate and to migrate to the site of injury, and there to fuse with the existing myofibres or to differentiate to form new fibres. ${ }^{7,8}$ Considering the key role of SCs in myofibre repair, previous studies have searched for the evidence of SC depletion or dysfunction. ${ }^{9-11}$ It appears that, primarily, there is an age-related loss of SC functionality and not SC numbers that underlies the loss of regenerative potential of aged skeletal muscle. ${ }^{12,13}$ Despite the huge number of studies, there is still no consensus as to whether age-related ineffective muscle regeneration is determined by changes in the extrinsic environment, which might inhibit the regenerative ability of otherwise competent SCs, or by agerelated impairment of SC function, due to intrinsic ageing of the resident stem cells that would render them less responsive to environmental cues, or instead by some combination of both of these conditions. ${ }^{14,15}$

In our previous studies, we demonstrated an age-related decrease in the antioxidant capacity of human SCs that might negatively affect the ability of aged SCs to repair muscle. ${ }^{16,17}$ Although there are distinct mechanisms that lead to sarcopenia, the most studied pathways are related to autophagy and the ubiquitin proteasome system, whereas although the caspases are activated in muscle wasting, their real roles remain controversial here. ${ }^{18}$

The caspases are a family of evolutionarily conserved cysteinyl proteases, and it is known that they mediate both apoptosis and inflammation through aspartate-specific cleavage of a wide number of cellular substrates. ${ }^{19}$ Apoptosis is a controlled form of cell death that has an essential role during embryonic development and in the maintenance of tissue homeostasis. Although there are many signalling pathways that initiate apoptosis, the main effectors belong

${ }^{1}$ Department of Neurosciences and Imaging, 'G. d'Annunzio' University, Chieti-Pescara, Italy; ${ }^{2}$ Stem Tech Group, Centre for Research into Ageing (CeSI), 'G. d'Annunzio' University, Chieti-Pescara, Italy; ${ }^{3} I I M-$ Interuniversity Institute of Myology, 'G. d'Annunzio' University, Chieti-Pescara, Italy; ${ }^{4}$ Department of Pharmacy, 'G. d'Annunzio' University, Chieti-Pescara, Italy; 'Laboratory of Molecular Genetics, Department of Psychological, Humanities and Territorial Sciences, 'G. d'Annunzio' University, Chieti-Pescara, Italy; ${ }^{6} \mathrm{CeSI}$, Ageing Research Center, 'G. d'Annunzio' University Foundation, Chieti, Italy and ${ }^{7}$ Section of Human Morphology, Department of Medicine and Ageing Sciences, 'G. d'Annunzio' University, Chieti-Pescara, Italy

*Corresponding author: R Di Pietro, Section of Human Morphology, Department of Medicine and Ageing Sciences, Building D, Level 1, 'G. d'Annunzio' University of Chieti-Pescara, Via dei Vestini, 31, Chieti 66100, Italy. Tel: +39 0871 3554567; Fax: +39 0871 3554568. E-mail: r.dipietro@ unich.it

Keywords: satellite cells; apoptosis; caspases; ageing

Abbreviations: SC, satellite cell; TUNEL, terminal deoxynucleotidyl transferase dUTP nick-end labelling; IPA, Ingenuity Pathway Analysis; ROS, reactive oxygen species; PDL, one population-doubling level; Desm + , desmin positive; z-VAD-fmk, Cbz-Val-Ala-Asp-fluoromethyl ketone; FLICA, fluorochrome inhibitor of caspases; AnnV, AnnexinV; DAPI, 4',6-diamidino-2-phenylindole; SSC, saline-sodium citrate

Received 22.8.13; revised 19.10.13; accepted 31.10.13; Edited by GM Fimia 
to the caspase family. To test the possibility of the involvement of the caspases in SC death in human ageing muscle, we analysed both the initiator caspases, namely, caspase-8 and caspase- 9 , and the effector caspases, namely, caspase-3, in the absence and presence of specific or broad pharmacologic inhibitors. Furthermore, to determine whether an age-related impairment prevents SCs from aged subjects from participating in tissue repair, we evaluated the expression of various genes that have critical roles in oxidative stress and cell death.

\section{Results}

Ageing makes SCs more susceptible to apoptosis. To assess any age-related differences in their susceptibility to apoptosis, we first used flow cytometry to quantify the percentages of AnnexinV $^{+}(\mathrm{AnnV})$ SCs after $4-72 \mathrm{~h}$ in culture. As shown in Table 1 and Figure 1, the percentages of apoptotic SCs obtained from old subjects ('aged SCs') were significantly $(P<0.05$ and $P<0.01)$ higher compared with those obtained from the young controls ('young SCs') at all of the experimental time points. Interestingly, this significant doubling in apoptotic-aged SCs occurred early (28.2 \pm 5.4 versus $14.4 \pm 1.9 \%$ for young SCs, at $4 \mathrm{~h}$ ) and was maintained to the same extent to the later time points.

The parallel detection of DNA strand breaks with the terminal deoxynucleotidyl transferase dUTP nick-end labelling (TUNEL) technique yielded consistent data that demonstrated a significantly $(P<0.05)$ greater percentage of TUNEL-positive nuclei in cultured aged SCs, in comparison with the young SC controls, at all of the experimental time points (Table 2 and Figures $2 a$ and b). Furthermore, $72 \mathrm{~h}$-cultured aged SCs displayed a fibroblast-like elongated shape and a greater size than the younger counterparts (data not shown). These findings are consistent with the observations of a progressive increase in the G0/G1 phase $(P<0.05$, aged SCs versus young SCs, at $24 \mathrm{~h}$ ), and moreover, of a reduction in the $\mathrm{S}$-phase proportion in the cell cycle in the aged SCs in comparison with the young SC controls $(P<0.05$, at 24 , and at $48 \mathrm{~h}$; Figure 2c). Thus, the young SCs showed an evident increase in the S-phase proportion at $24 \mathrm{~h}$, at the expense of the G0/G1 phase, and in the G2/M phase at $72 \mathrm{~h}$, in comparison with the aged SC counterparts $(P<0.05$; Figure 2c). Surprisingly, whatever the duration of the in vitro culture, there was no hypo-diploid peak (sub-G0/G1 cell population) detected in the cell cycle profiles of the aged SCs (Figure 2d). This finding can be justified either by the absence of the typical DNA fragmentation at the nucleosomal level or by the incomplete execution of the apoptotic programme with the resulting degeneration in apo-necrosis or necrosis of cells that cannot repair their DNA during the G0/G1 phase of the cell cycle.

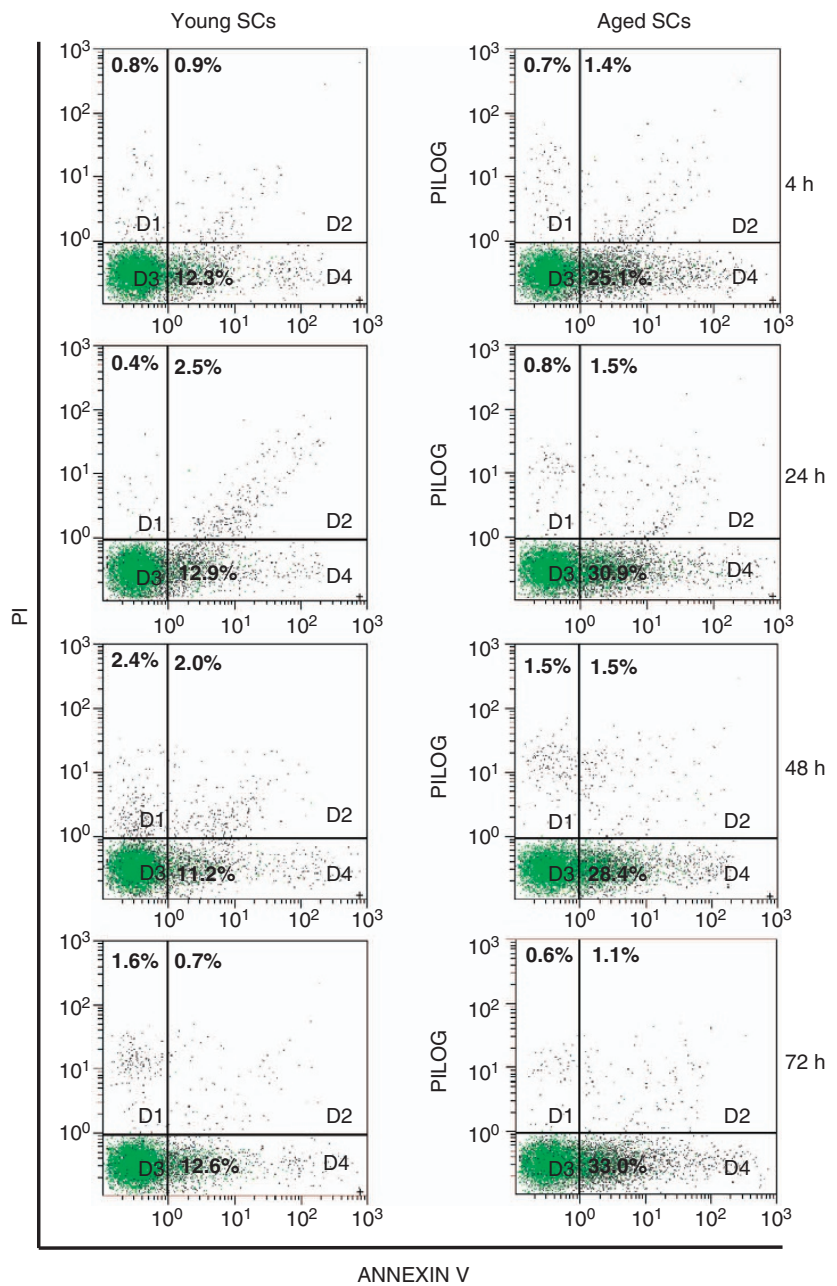

Figure 1 Flow cytometry dot plots of different cell populations in young SCs (left) and aged SCs (right) cultured for 4, 24, 48, and $72 \mathrm{~h}$, as indicated. Early apoptotic cells $\left(\mathrm{AnnV}^{+} / \mathrm{PI}^{-}\right.$, quadrant $\left.\mathrm{D} 4\right)$ can be discriminated from viable cells $\left(A n n V^{-} / \mathrm{PI}^{-}\right.$, quadrant $\left.\mathrm{D} 3\right)$, late apoptotic cells $\left(\mathrm{AnnV}^{+} / \mathrm{PI}^{+}\right.$, quadrant $\left.\mathrm{D} 2\right)$, and necrotic cells ( $A n n V^{-} / \mathrm{PI}^{+}$, quadrant $\left.\mathrm{D} 1\right)$, according to their fluorescence emission

Table 1 Annexin V/PI detection in flow cytometry of apoptotic and necrotic/late apoptotic cells in satellite cells of young and aged subjects

\begin{tabular}{|c|c|c|c|c|c|c|}
\hline \multirow{3}{*}{$\begin{array}{l}\text { Time } \\
\text { (h) }\end{array}$} & \multicolumn{6}{|c|}{ Apoptotic and necrotic/late apoptotic satellite cells } \\
\hline & \multicolumn{3}{|c|}{ Young satellite cells } & \multicolumn{3}{|c|}{ Aged satellite cells } \\
\hline & AnnexinV ${ }^{+} / \mathrm{PI}^{-}$ & AnnexinV ${ }^{+} / \mathbf{P I}^{+}$ & AnnexinV $\mathbf{V}^{-} \mathrm{PI}^{+}$ & AnnexinV ${ }^{+} / \mathrm{PI}^{-}$ & AnnexinV $^{+} / \mathrm{PI}^{+}$ & AnnexinV $\mathbf{P}^{-} \mathrm{PI}^{+}$ \\
\hline $\begin{array}{l}4 \\
24 \\
48 \\
72\end{array}$ & $\begin{array}{l}14.4 \pm 1.9^{\star} \\
15.5 \pm 3.0^{\star} \\
14.4 \pm 4.5^{\star \star} \\
16.8 \pm 7.3^{\star \star}\end{array}$ & $\begin{array}{l}2.4 \pm 1.0 \\
3.4 \pm 1.4 \\
0.9 \pm 0.4 \\
0.9 \pm 0.5\end{array}$ & $\begin{array}{l}2.9 \pm 1.9 \\
2.9 \pm 1.2 \\
1.8 \pm 0.5 \\
0.7 \pm 0.5\end{array}$ & $\begin{array}{l}28.2 \pm 5.4 \\
33.1 \pm 7.3 \\
27.8 \pm 3.5 \\
33.7 \pm 4.8\end{array}$ & $\begin{array}{l}4.0 \pm 1.6 \\
3.4 \pm 0.7 \\
2.0 \pm 0.7 \\
1.5 \pm 0.8\end{array}$ & $\begin{array}{l}1.4 \pm 0.6 \\
2.5 \pm 0.9 \\
1.4 \pm 0.3 \\
0.8 \pm 0.4\end{array}$ \\
\hline
\end{tabular}

AnnexinV ${ }^{+} / \mathrm{PI}^{-}$: young SCs versus aged SCs: ${ }^{*} P<0.05 ;{ }^{* *} P<0.01$ 
Table 2 Detection in light microscopy of TUNEL-positive cells in satellite cells of young and aged subjects. Data are means \pm S.D. of three independent experiments

TUNEL-positive satellite cells

\begin{tabular}{lcc}
\hline Time (h) & Young satellite cells & Aged satellite cells \\
\hline 4 & $18.4 \pm 3.3^{*}$ & $30.5 \pm 4.3$ \\
24 & $24.9 \pm 2.2^{*}$ & $36.2 \pm 5.1$ \\
48 & $19.7 \pm 1.6^{\star}$ & $30.4 \pm 2.5$ \\
72 & $22.0 \pm 1.3^{*}$ & $33.5 \pm 2.8$ \\
\hline
\end{tabular}

TUNEL-positive cells in young SCs versus aged SCs: ${ }^{*} P<0.05$

The caspase enzymes have dual roles in SCs from old and young subjects. To investigate whether the caspases are involved in this SC apoptotic cell death, we first took into consideration the expression and activity of the initiator caspases that are responsible for extrinsic (caspase-8) and intrinsic (caspase-9) apoptotic pathway recruitment. Unexpectedly, caspase-8 activity was greater in the young SCs at 4, 24, and $48 \mathrm{~h}(P<0.01$ versus aged SCs, at $24 \mathrm{~h}$; Figure $3 \mathrm{a})$ and, more surprisingly, the percentage of AnnV/propidium iodide (PI)-positive cells was greater in the young SCs, and significantly greater than that of the aged SCs after $24 \mathrm{~h}$ of in vitro treatment with a caspase-8-specific pharmacological inhibitor $(P<0.05$; Figure $3 \mathrm{~b})$. These observations were paralleled by the significant reduction in cell proliferation in the young SCs at $24 \mathrm{~h}$ after treatment with the caspase-8 inhibitor $(P<0.05$; Figure 3c). Furthermore, the in vitro treatment with a caspase-9-specific inhibitor led to a significant increase in the percentage of AnnV/PI-positive young SCs, but to a parallel significant decrease in AnnV/PIpositive aged SCs, in comparison with both the aged SCs in the absence of this inhibitor and, moreover, the young SCs in the presence of this inhibitor $(P<0.05$, at $4 \mathrm{~h}$; Figure $3 \mathrm{~d})$, thus indicating a dual role of caspase- 9 in the SC age groups under consideration. Interestingly, at $24 \mathrm{~h}$, the aged SCs showed an increase in AnnV/PI labelling in the presence of the caspase-9 inhibitor, as seen for the young SCs at an earlier time point (Figure 3d). In spite of this effect, in the aged SCs there were no significant changes in the cell cycle distribution and no development of a hypo-diploid peak was seen (data not shown).

When considering the transcript expression of apoptotic genes, it was interesting to note that for all of the caspase genes examined (except for CASP7), and in particular for $C A S P 2$ and $C A S P 9$, there was early upregulation in the aged SCs (Figure 4a). Also of particular note, CASP6 and CASP9 gene expression was increased in the aged SCs at all of the time intervals under investigation (4-72 h; Figure 4). In contrast, the $F A D D$ gene, which encodes a protein recruited by the Fas- $L$ receptor, was downregulated at all of the time points tested (Figure 4). This is consistent with reduced activation of caspase-8 in the aged SCs, which is known to trigger apoptosis in response to extrinsic stimuli. ${ }^{20}$ Moreover, the $B A D$ gene, the protein product of which positively regulates cell apoptosis by forming heterodimers with BCL$\mathrm{xL}$ and $\mathrm{BCL}-2$, was downregulated at 4 and at $48 \mathrm{~h}$ but upregulated at 24 and at $72 \mathrm{~h}$ (Figure 4); this suggests the involvement of the 'intrinsic pathway' of apoptotic cell death. ${ }^{20}$ Of note, the significant increase in CASP3 gene transcription at $72 \mathrm{~h}$ (Figure $4 \mathrm{~d}$ ) was consistent with the activation of caspase-3 at both the nuclear and cytoplasmic levels in the aged SCs at $72 \mathrm{~h}$, whereas in the young SCs, the active caspase-3 enzyme was localised only at the nuclear level (Figure 5a). Furthermore, caspase-3 activation did not correlate with the expression of known differentiation markers in the aged SCs, such as myogenin (Figure 5a).

To finally dissect out the role of the caspase enzymes in the aged SCs, we treated the cell cultures with a broad caspase inhibitor, Cbz-Val-Ala-Asp-fluoromethyl ketone (z-VAD-fmk), for up to $24 \mathrm{~h}$. Here, z-VAD-fmk led to opposite age-related effects, as there was a decrease in the percentage of AnnV/ $\mathrm{PI}$-positive aged SCs, whereas this percentage increased to threefold in the young SCs, at $24 \mathrm{~h}(P<0.001$; Figure $5 \mathrm{~b})$. Of note, upon inhibition of all of the caspase enzymes with $z-V A D-f m k$, there was an early increase in the $S$ phase in the young SCs (at $4 \mathrm{~h}$ ) that was followed by an enlarged G2/M phase at $24 \mathrm{~h}(P<0.05)$; in contrast, the G0/G1 phase was already increased in the aged SCs at $4 \mathrm{~h}$, and was further increased at $24 \mathrm{~h}$, in comparison with both the untreated samples and, moreover, the young SCs $(P<0.05$, at $4 \mathrm{~h}$; Figure 5c).

Genes involved in cell death and stress response pathways are differentially expressed in SCs from old and young subjects. Sets of age-related dysregulated genes were identified using DNA microarrays, and were further analysed using the Ingenuity Pathway Analysis (IPA) software, to determine the eligible gene networks and key biological functions. In proliferating SCs from aged humans at the start of the experiments $(0 \mathrm{~h}) 52$ genes were upregulated and only 1 gene was downregulated. Interestingly, the top function that was upregulated at time 0 was represented by 17 cell death genes (Figures $6 a$ and b), several of which (ETS1, F2R, GPX4, MCL1, PRKCl, RBBP4, SHC1, SMAD4, THOC1, TRIM28, and ZMAT3) are related to the caspase pathway. As well as cell death, the main SC functions involved were cell growth and proliferation, cell morphology, cellular assembly and organisation, free radical scavenging, cellular compromise, molecular transport, and skeletal and muscular system development and function (Figures $6 a$ and b). The first of the three most significant networks included nodes of genes that are involved in cell death (SMAD4 and MMP1; Figure 6c); the second network included nodes of genes that have important roles in cell death (MCL1), actin stress fibre formation (RBBP4 and ITGAV), and muscle development and morphogenesis (DLG1 and SHC1; Figure 6d); and the third network included nodes of genes that have functions in apoptotic pathways (F2R, GNB2, and DEGS1; Figure 6e).

\section{Discussion}

Previous studies carried out in our own and other laboratories have demonstrated the accumulation of reactive oxygen species (ROS) and significant decreases in endogenous antioxidant mechanisms (for example, catalase and glutathione $S$-transferase activities) in aged human skeletal 
a

$4 \mathrm{~h}$

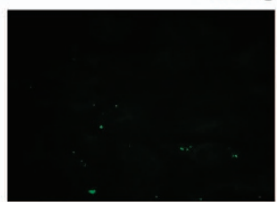

Young SCs

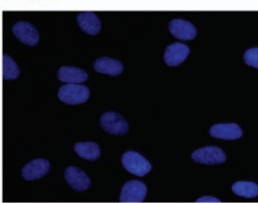

$24 \mathrm{~h}$
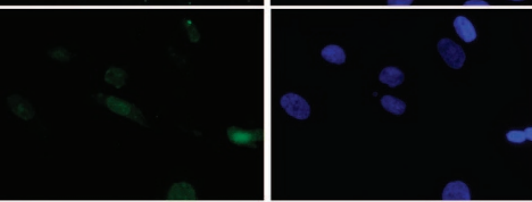

$48 \mathrm{~h}$
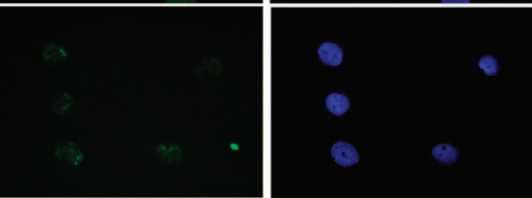

$72 \mathrm{~h}$
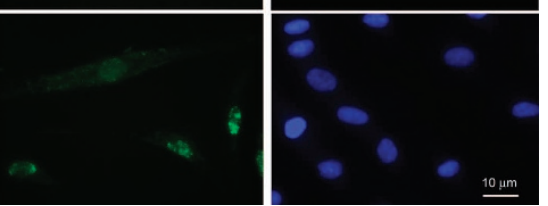

b

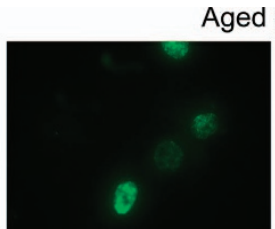

Aged SCs

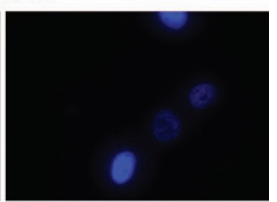

$24 \mathrm{~h}$
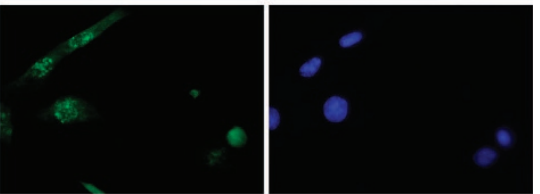

$48 \mathrm{~h}$
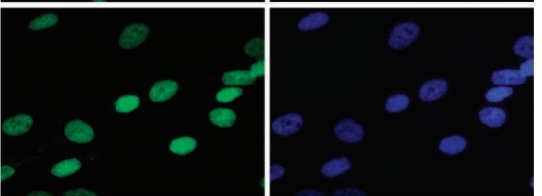

$72 \mathrm{~h}$

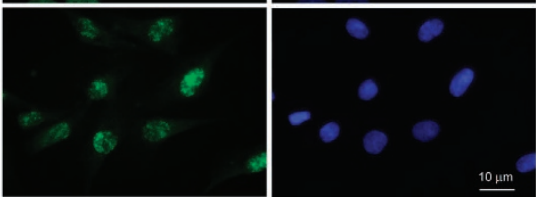

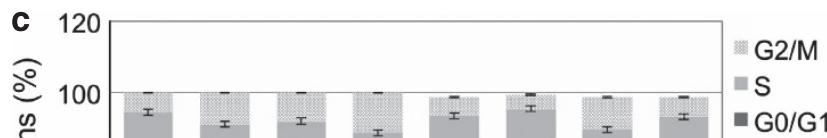

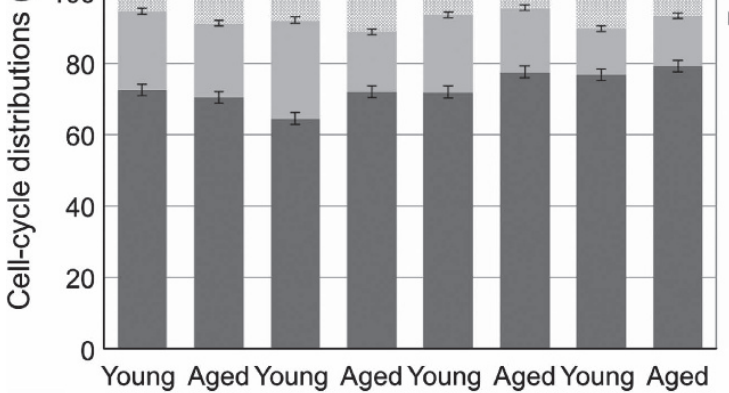

$4 \mathrm{~h} \quad 24 \mathrm{~h} \quad 48 \mathrm{~h} \quad 72 \mathrm{~h}$
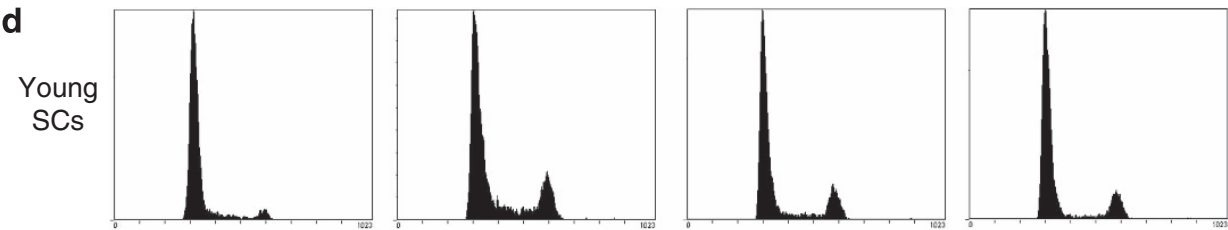

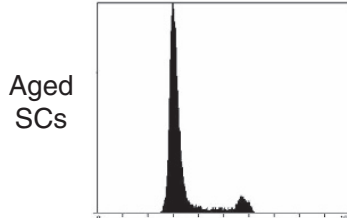

$4 \mathrm{~h}$

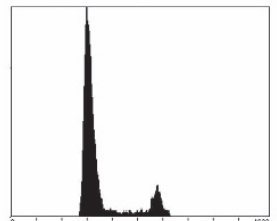

$24 \mathrm{~h}$

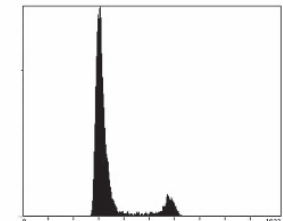

$48 \mathrm{~h}$

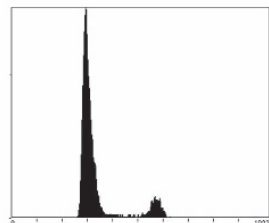

72 h

Figure 2 Fluorescence images of young SCs (a) and aged SCs (b) assayed with the TUNEL technique at different time intervals of in vitro culture, as indicated. Nuclei were counterstained with DAPI (blue fluorescence). Green (TUNEL) and blue fluorescence (DAPI) single emissions are shown in the left and right panels, respectively. Representative fields from a representative experiment of the three independent experiments are shown. Original magnification: $\times 40$. Scale bar: $10 \mu \mathrm{m}$. (c) Cell cycle distributions of young SCs and aged SCs at different time intervals of in vitro culture, as indicated. Data are means \pm S.E. of three independent experiments. Significant differences are seen for aged SCs versus young SCs: for G0/G1 at $24 \mathrm{~h}(P<0.05)$; for $\mathrm{S}$ at $24 \mathrm{~h}(P<0.05)$; for $\mathrm{S}$ at $48 \mathrm{~h}(P<0.05)$; for G2/M at $72 \mathrm{~h}(P<0.05)$. (d) Cell cycle profiles of young SCs and aged SCs at 4, 24, 48 , and $72 \mathrm{~h}$ of in vitro culture, as indicated, showing absence of any hypo-diploid peak. A representative experiment of three independent experiments is shown 


\section{a}
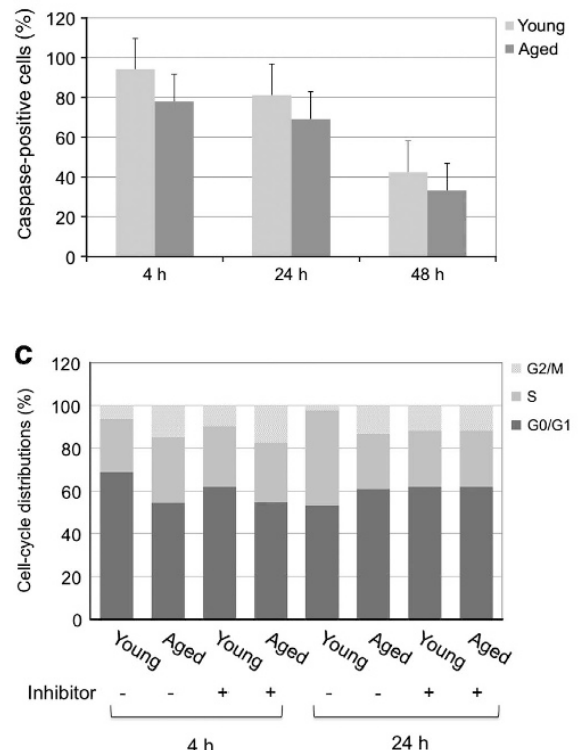
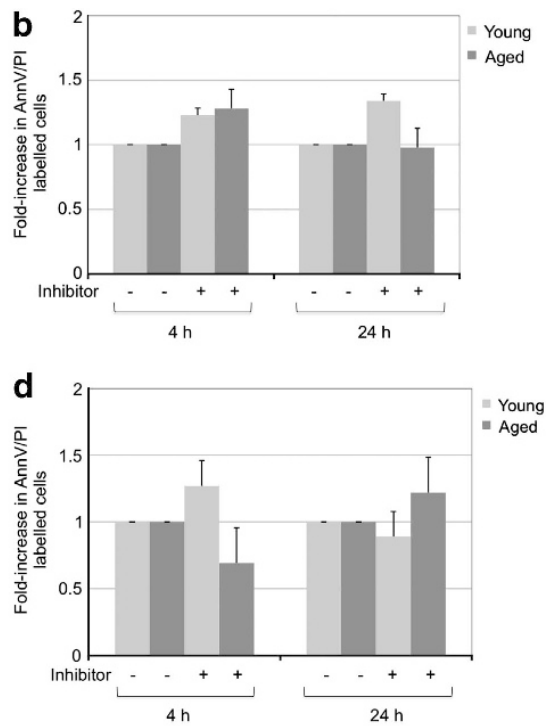

Figure 3 (a) Caspase-8 activation in young SCs and aged SCs at different time intervals of in vitro culture, as indicated. Data are means \pm S.E. of three independent experiments. A significant difference is seen for aged SCs versus young SCs at $24 \mathrm{~h}(P<0.01)$. (b) Fold-increase in AnnV/PI-labelled young SCs and aged SCs with and without administration of a caspase-8-specific inhibitor, as indicated. The data were obtained at 4 and $24 \mathrm{~h}$ and were normalised to the AnnV/PI-labelled cell levels without the inhibitor, as means \pm S.E. of three independent experiments. A significant difference is seen for aged SCs versus young SCs at $24 \mathrm{~h}(P<0.05)$. (c) Cell cycle distributions of young SCs and aged SCs at different time intervals of in vitro culture without and with administration of a caspase-8-specific inhibitor, as indicated. A representative experiment of three independent experiments is shown. (d) Fold-increase in AnnV/PI-labelled young SCs and aged SCs with and without administration of a caspase-9-specific inhibitor. The data were obtained at 4 and $24 \mathrm{~h}$ and were normalised to the AnnV/PI-labelled cell levels without the inhibitor, as means \pm S.E. of three independent experiments. A significant difference is seen for aged SCs versus young SCs at $4 \mathrm{~h}(P<0.05)$

a
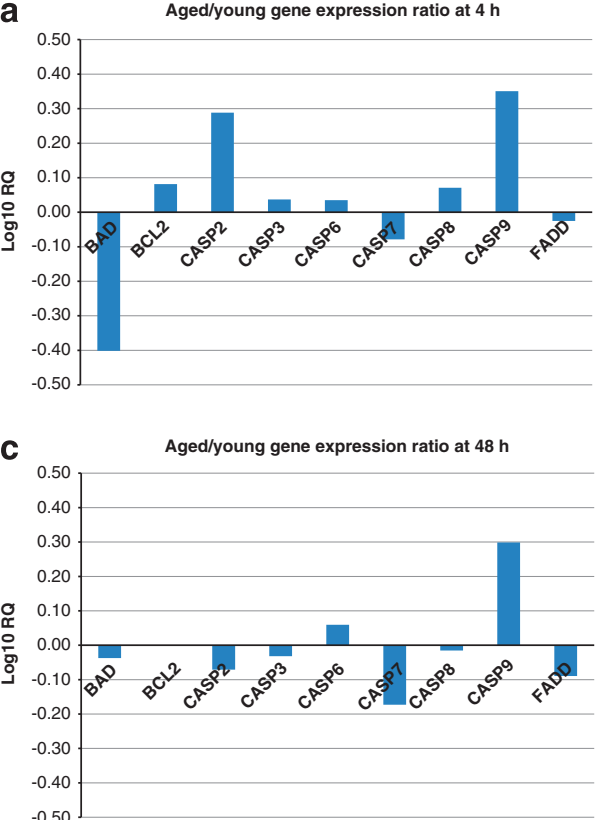

b

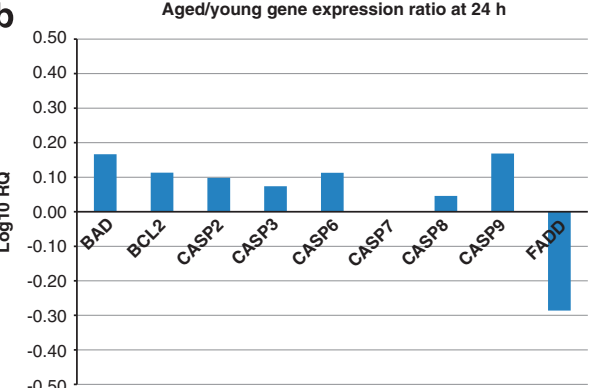

d

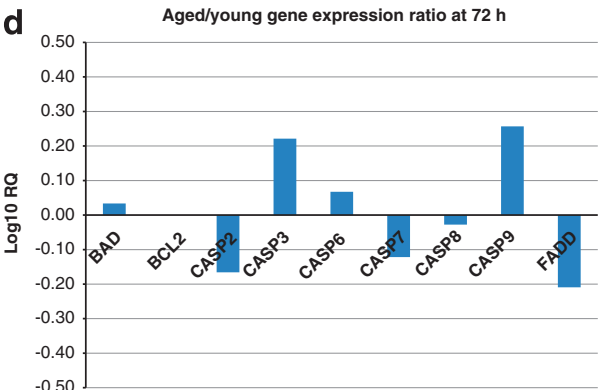

Figure 4 Expression levels of genes representative of the apoptosis pathway, analysed with RT-PCR using TaqMan low density arrays. Data from the log ${ }_{10}$ of relative quantifications of the transcripts for the target genes versus GAPDH gene expression are represented as the aged SCs to young SCs ratios, as indicated, following in vitro culture for $4 \mathrm{~h}(\mathbf{a}), 24 \mathrm{~h}(\mathbf{b}), 48 \mathrm{~h}(\mathbf{c})$ and $72 \mathrm{~h}(\mathrm{~d})$

muscle, with a consequent increase in oxidative damage to DNA and lipids. ${ }^{16,21}$ Here, we show for the first time that in human subjects, the SCs from aged vastus lateralis skeletal muscle are more susceptible to spontaneous apoptosis than the young SC controls, as they show a significantly greater percentage of AnnV-positive cells after 4-72 $\mathrm{h}$ in culture in the presence of serum and growth factors. As expected, this percentage was even greater when the aged SCs were 


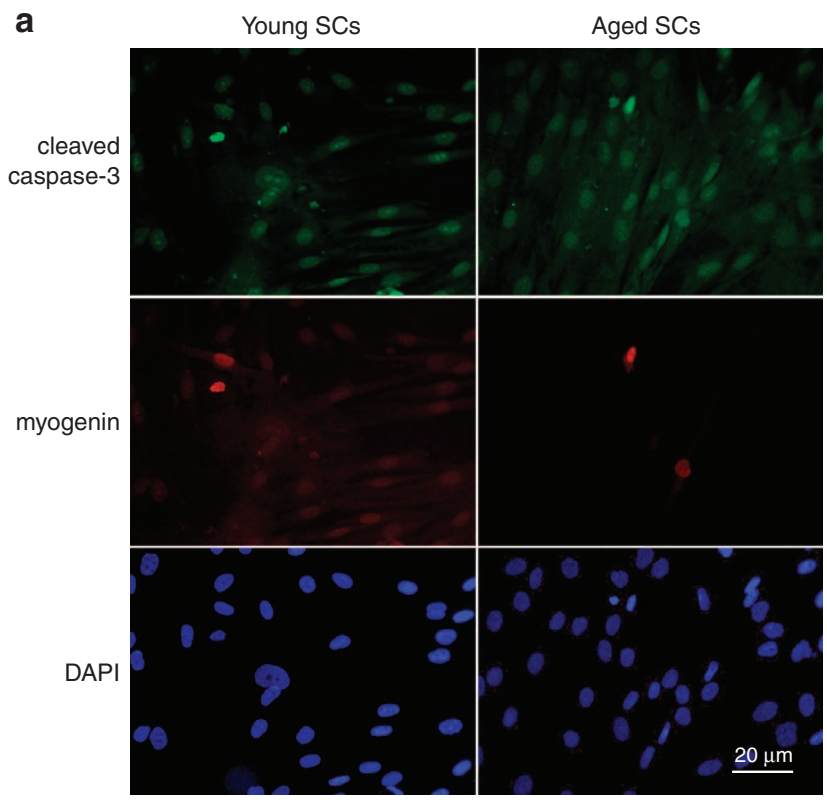

b
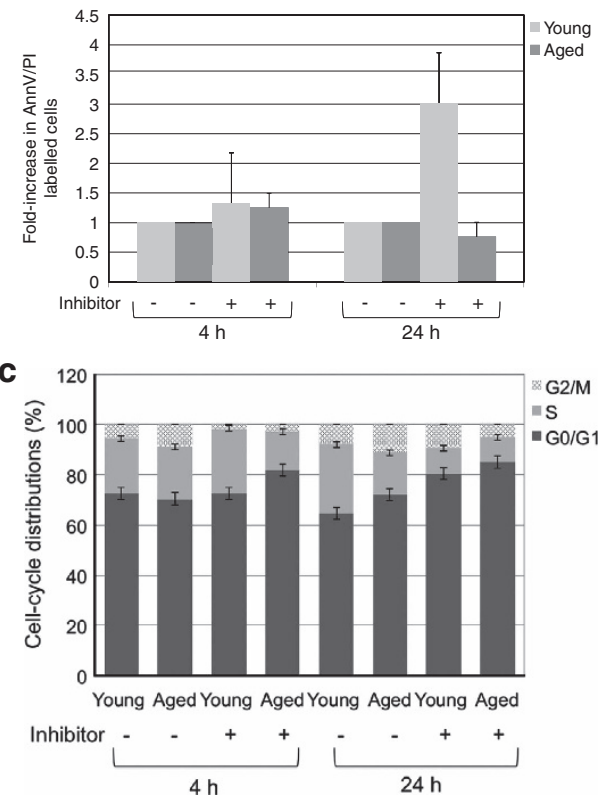

Figure 5 (a) Immunofluorescence images of cleaved caspase-3/myogenin detection in young SCs (left) and aged SCs (right) following in vitro culture for $72 \mathrm{~h}$. Green (cleaved caspase-3), red (myogenin), and blue (DAPI) fluorescence single emissions are shown, as indicated. Of note, the nuclear and cytoplasmic location of caspase-3 is appreciable only in the aged SCs. Representative fields from a representative experiment of the three independent experiments is shown. Magnification: $\times 20$. Scale bar: $20 \mu \mathrm{m}$. (b) Fold-increase in AnnV/PI-labelled young SCs and aged SCs with and without administration of the broad caspase inhibitor Z-VAD-fmk. Data were obtained at 4 and $24 \mathrm{~h}$ and were normalised to the AnnV/PI-labelled cell levels without the inhibitor, as means \pm S.E. of three independent experiments. A significant difference is seen for aged SCs versus young SCs at $24 \mathrm{~h}(P<0.001)$. (c) Cell cycle distributions of young SCs and aged SCs at different time intervals of in vitro culture with and without administration of the broad caspase inhibitor z-VAD-fmk, as indicated. Data are means \pm S.E. of three independent experiments. Significant differences are seen for aged SCs versus young SCs: for G0/G1 at $4 \mathrm{~h}(P<0.05)$; for $\mathrm{S}$ at $4 \mathrm{~h}(P<0.05)$; for $\mathrm{G} 2 / \mathrm{M}$ at $24 \mathrm{~h}(P<0.05)$

cultured under starvation conditions (our unpublished observations), and is consistent with the increased number of TUNEL-positive SCs in the elderly, which indicates the occurrence of DNA single- and double-strand breaks.

This observation is in line with previous findings that have demonstrated that murine myoblasts are susceptible to apoptosis versus post-mitotic syncytia resistance during differentiation. ${ }^{22,23}$ The occurrence of DNA single-/doublestrand breaks was related to caspase-3 activation and was not related to the differentiation capability of the aged SCs. Caspase- 3 has been extensively characterised as a regulator of cellular DNA fragmentation in numerous models of skeletal muscle atrophy, including the burn injury, heart failure cachexia, and hindlimb suspension. ${ }^{24}$ Numerous cellular mechanisms lead to caspase-3 activation, including mitochondria-dependent (for example, cytochrome $c$ release) and mitochondria-independent (for example, $\mathrm{Ca}^{2+}$ activation of calpain) pathways that result in the stimulation of the DNases responsible for cellular DNA fragmentation and protein degradation. ${ }^{20,25}$ However, the specific roles of the single caspase proteases in aged SCs remain to be clarified. Our data indicate an age-related dual role of the caspase pathway.

Indeed, as the initiator caspase that is canonically involved in the 'extrinsic pathway', caspase-8 is more active in the young SCs, and, when inhibited, leads to an unexpected increase in AnnV/PI labelling in these young SCs that is accompanied by a reduction in S-phase cells, which indicates its possible role in mediating differentiation more than cell death in these young SCs, as has also been reported recently. ${ }^{23}$ In contrast, the gene expression for caspase-9, together with caspase-6, is early and long-lasting in the aged SCs. Moreover, inhibition of the caspase-9 enzyme activity results in a significant reduction in the number of AnnV/PIlabelled cells, although this effect is reversed at $24 \mathrm{~h}$.

Interestingly, these age-related opposite effects on the cell cycle phase distributions arose from inhibition of all of the caspase enzymes with z-VAD-fmk, at 4 and $24 \mathrm{~h}$, which suggests the action of the caspase enzymes on different targets involved in cell cycle regulation. Other studies have demonstrated that the process of myogenic differentiation is associated with typical apoptotic signalling, such as caspase3 activation, which is not just coincident with differentiation but necessary for progression of differentiation. ${ }^{26}$ Although differentiation-associated apoptotic signalling might positively contribute to myogenic differentiation, ${ }^{27}$ it might also have negative effects, leading to erroneous cell death. ${ }^{28}$

We hypothesise that the abnormal accumulation of ROS that characterises aged $\mathrm{SCs}^{29,30}$ through the perturbation of the pro-apoptotic and anti-apoptotic 'rheostat' might trigger the mitochondria-dependent pathway and promote SC death. This hypothesis is supported by the data obtained with our IPA analysis that demonstrated age-related upregulation of the $P R K C l$ gene, which has a role in the oxidative response, ${ }^{31}$ and of $S H C 1$, which is related to ROS production in mouse $\mathrm{SCs}^{32}$ and can activate caspase- 8 and promote apoptosis in RAT-2 fibroblasts. ${ }^{33}$ Moreover, the age-related SC susceptibility to 
cell death was confirmed by the upregulation of the THOC1 gene in the aged SCs, which has been reported to regulate proteolysis of caspase- 6 and caspase- $9,{ }^{33}$ and of other genes like SMAD4, ${ }^{34} \mathrm{TRIM}_{28},{ }^{35} \mathrm{ZMAT3}^{36}{ }^{36} \mathrm{MCL} 1,{ }^{37}$ and $\mathrm{GPX} 4{ }^{38}$ most of which are involved in caspase-3 activation.

In summary, no stressors or apoptotic inducers were used in the present study, as we wanted to evaluate apoptosis that spontaneously occurs during in vitro primary culture of human SCs. Our findings highlight an increased rate of spontaneous apoptosis in the aged SCs, which supports the hypothesis of an intrinsic ageing of $\mathrm{SCs}^{14,15}$ and which are in line with previous reports that have demonstrated increased susceptibility to apoptosis of SCs from older animals. ${ }^{11}$ This was demonstrated here using flow cytometry analysis of AnnV/PI staining, the TUNEL technique, the presence of the death genes data set and the activated caspases. These factors imply that, compared with the young SCs, a greater proportion of the aged SCs undergoes programmed cell death in vivo in response to stress stimuli, thereby impairing skeletal muscle regeneration.

\section{Materials and Methods}

Subjects, SC culture, and treatments. The SC populations were isolated from muscle fragments obtained from vastus lateralis biopsies of nine healthy young subjects ( $27.3 \pm 2.0$ years old; 'young SCs') and nine healthy old subjects (71.1 \pm 1.8 years old; 'aged SCs'), after written informed consent and approval from the ethics committee of the ' $G$. d'Annunzio' University of Chieti-Pescara (protocol numbers: 1233/06 COET, dated 25 July 2006; 1884 COET, dated 15 May 2009; and 1634/08 COET, dated 24 June 2008). ${ }^{39}$ The inclusion criteria were as follows: normal ECG and blood pressure; lack of bone and joint disorders, or metabolic (that is, diabetes) and/or cardiovascular diseases. The exclusion criteria were as follows: the presence of metabolic and/or cardiovascular diseases, evidence of hereditary or acquired muscular disorders, diagnosis of respiratory disorders or psychiatric problems. No subject had been taking testosterone or other pharmacological therapies known to influence muscle mass. The first mononuclear cells migrated out of the explants within 7-13 days from the beginning of the culture (independent of donor age), and these were removed. For cell growth, the SCs were cultured in growth medium containing HAM's F-10 (Gibco by Invitrogen, Carlsbad, CA, USA), supplemented with $50 \mu \mathrm{g} / \mathrm{ml}$ gentamycin and $20 \%$ fetal calf serum (Hyclone, Logan, UT, USA). At the first cell passage when explants were removed, all of the cell populations were taken as 'one population-doubling level' (PDL). Cell populations were trypsinised and replated after reaching $50 \%$ confluency. The number of population doublings (expressed as PDL) at every passage was calculated as $\log N / \ln 2$, where $N$ is the number of cells at the time of passage divided by the number of cells initially attached after seeding (Nt/Ni). Cultures were termed 'senescent' when they failed to display one mean doubling after 3 weeks of re-feeding. ${ }^{40}$ The culture life spans were 55-65 PDL for newborns, 15-20 PDL for young adults, and 12-20 PDL for the elderly.

Experiments were carried out on SCs under 4, 24, 48, and $72 \mathrm{~h}$ of culture (15.7 PDL for young SCs and 12.2 PDL for aged SCs) after assaying the myogenic index by scoring the number of desmin-positive (Desm +) cells. At least 1500-2000 nuclei were counted in 25-30 different randomly selected fields. The mean values of $60.0 \pm 7.3 \%$ Desm + cells in the young SCs and $52.6 \pm 3.8 \%$ Desm + cells in the aged SCs were considered as standard for the experiments. At each time point, the cells were pre-incubated for $45 \mathrm{~min}$ with the specific pharmacological inhibitors of caspase-8 $(20 \mu \mathrm{M} \quad z-\mathrm{IE}(\mathrm{OMe}) \mathrm{TD}(\mathrm{OMe})$-fmk) or caspase-9 (50 $\mu \mathrm{M} \quad \mathrm{z}-\mathrm{LE}(\mathrm{OMe})$ $\mathrm{HD}(\mathrm{OMe})-f m k)$, and in some cases, with the broad inhibitor of caspase proteases, z-VAD-fmk $(20 \mu \mathrm{M})$. All of these compounds were purchased from Calbiochem (La Jolla, CA, USA), and they do not represent physiological inhibitors of caspases but synthetic peptides that act as pseudosubstrates for the active caspases, and therefore that behave as competitive inhibitors of these enzymes.

Annexin V/PI detection with flow cytometry. Early apoptotic cells can be recognised through reversible binding of AnnV to phosphatidylserine, a membrane phospholipid that is exposed at the beginning of the apoptotic process. ${ }^{41}$ To assess apoptosis of these SCs, commercial kits (human AnnVfluorescein isothiocyanate (FITC) kits; Bender MedSystem, Vienna, Austria) were used, as previously described. ${ }^{42,43}$ Briefly, the cells were gently resuspended in binding buffer and incubated for $10 \mathrm{~min}$ at room temperature (RT) in the dark with AnnV-FITC. The samples were then washed and supravitally stained with PI $(50 \mu \mathrm{g} / \mathrm{ml})$, a membrane impermeable stain that discriminates between membrane-altered necrotic (bright) and apoptotic (dim) cells. Analyses were performed with an EPICS Coulter flow cytometer, with the FL3 detector in the log mode, using the EXPO32 analysis software (Beckman Coulter Inc., Brea, CA, USA). For each sample, 10000-20000 events were collected. Viable cells were $A n n V^{-} / \mathrm{PI}^{-}$, early apoptotic cells were $A n n V^{+} / \mathrm{PI}^{-}$, late apoptotic cells were $A n n V^{+} / \mathrm{PI}^{+}$, and necrotic cells were $A n n V^{-} / \mathrm{PI}^{+}$.

DNA analysis for flow cytometry. Approximately $25 \times 10^{4}$ cells per experimental condition were collected, fixed in $70 \%$ cold ethanol, and kept overnight at $4^{\circ} \mathrm{C}$. The cells were then resuspended in $20 \mu \mathrm{g} / \mathrm{ml} \mathrm{PI}$ and $100 \mu \mathrm{g} / \mathrm{ml}$ RNAse, final concentrations. The cell cycle profiles were analysed with an EPICS-XL cytometer, using the EXPO32 software (Beckman Coulter Inc.) as previously described. ${ }^{42,43}$ The cells with low fluorescence levels indicated their low DNA content, and these were gated as dead cells. The data were analysed using the Multicycle software (Phoenix Flow Systems, San Francisco, CA, USA).

Immunofluorescent staining of DNA strand breaks. To visualise possible DNA damage on a per-cell basis that was caused by endogenous endonuclease activation, we performed in situ TUNEL assays on the same samples, which detect single or double DNA strand breaks through labelled nucleotides polymerised to free $3^{\prime}$-hydroxyl termini in a reaction catalysed by terminal deoxynucleotidyl transferase. ${ }^{44}$ For the TUNEL assays, the cells were fixed in paraformaldehyde (4\% v/v in phosphate-buffered saline (PBS), $\mathrm{pH} 7.4$ ) for $30 \mathrm{~min}$ at RT, and then incubated in a permeabilising solution $(0.1 \%$ Triton $\mathrm{X}-100$, $0.1 \%$ sodium citrate) for $2 \mathrm{~min}$ on ice. DNA strand breaks were identified with in situ Cell Death detection kits (Boehringer Mannheim, Mannheim, Germany), as previously described. ${ }^{43}$ Slides were counterstained with 4',6-diammino-2phenylindole (DAPI) (Vector Laboratories, Burlingame, CA, USA), mounted in glycerol, and observed under a ZEISS Axioskop 40 (Carl Zeiss, Göttingen, Germany) light microscope, equipped with a Coolsnap Videocamera (Photometrics, Tucson, AZ, USA), for acquiring digital images. The extent of DNA fragmentation was quantified through direct visual counting of green fluorescencelabelled nuclei at $\times 40$ magnification. Five slides per sample were examined, and the apoptotic cells were scored out of a total of 100 cells. Positive control samples consisted of SCs treated with $3 \mu \mathrm{g} / \mathrm{ml}$ deoxyribonuclease I for $10 \mathrm{~min}$ at RT.

Measurement of caspase activation. Two different methods were used to better analyse the caspase activation. To assess caspase-8 activation, fluorochrome inhibitor of caspases (FLICA) Apoptosis Detection kits were used (Immunochemistry Technologies, Bloomington, MN, USA). These kits are based on a fluorochrome inhibitor of the caspases. Once inside the cell, the FLICA inhibitor binds covalently to active caspases. ${ }^{45}$ To determine the caspase activation, $300 \mu \mathrm{l}$ of each cell suspension was transferred to sterile tubes. After adding $10 \mu \mathrm{l}$ FLICA solution to these cell suspensions, the cells were left to incubate for $1 \mathrm{~h}$ at $37^{\circ} \mathrm{C}$ in the dark. Then $2 \mathrm{ml}$ wash buffer was added to each tube, and the cells were centrifuged at $400 \times g$ for $5 \mathrm{~min}$. After centrifugation, the supernatant was discarded and the cell pellet was resuspended in wash buffer. Cells were centrifuged again at $400 \times g$ for $5 \mathrm{~min}$, and the supernatant was decanted. The cell pellet was finally resuspended in $400 \mu \mathrm{l}$ wash buffer and analysed using an EPICS Coulter flow cytometer, with the FL3 detector in log mode, using the EXPO 32 analysis software.

To assess caspase- 3 activation, the cells were fixed for $10 \mathrm{~min}$ with $3 \%$ paraformaldehyde at RT in Dulbecco's PBS (DPBS), pH 7.6, supplemented with 2\% sucrose. Then, the cell membranes were permeabilised for $5 \mathrm{~min}$ at $\mathrm{RT}$ in a pH 7.6 solution containing $0.5 \%$ Triton X-100, $20 \mathrm{mM}$ HEPES, $300 \mu \mathrm{M}$ sucrose, $50 \mathrm{mM}$ $\mathrm{NaCl}$, and $3 \mathrm{mM} \mathrm{MgCl}_{2}$. After membrane permeabilisation, the cells were incubated with $10 \%$ bovine serum albumin (BSA)/DPBS, followed by incubation with a rabbit monoclonal anti-cleaved caspase-3 (Cell Signaling Technology, Beverly, MA, USA) diluted 1:200 in 1\% BSA/DPBS, for 45 min at RT. After several washings with PBS, the primary antibody was recognised using goat anti-rabbit IgG TRITC (Jackson Immuno Research, West Grove, PA, USA) diluted 1:50 in 1\% BSA/DPBS, for $60 \mathrm{~min}$ at RT. The slides were counterstained with DAPI (Vector Laboratories), mounted in glycerol, and observed under a light microscope, as specified above. 
a

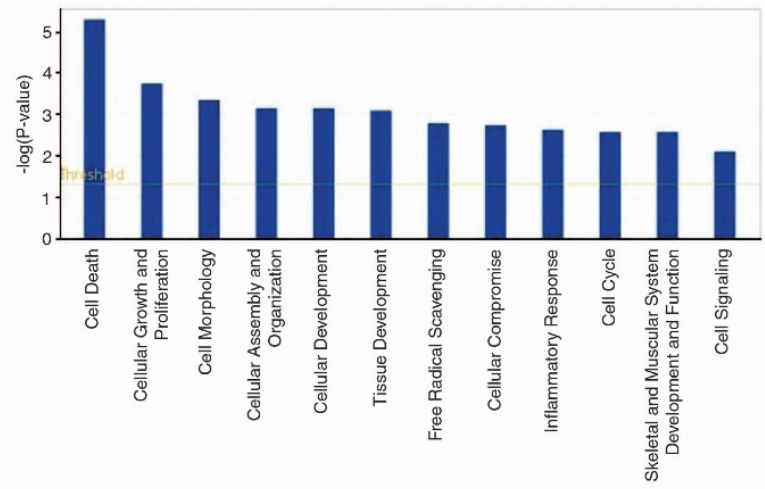

C

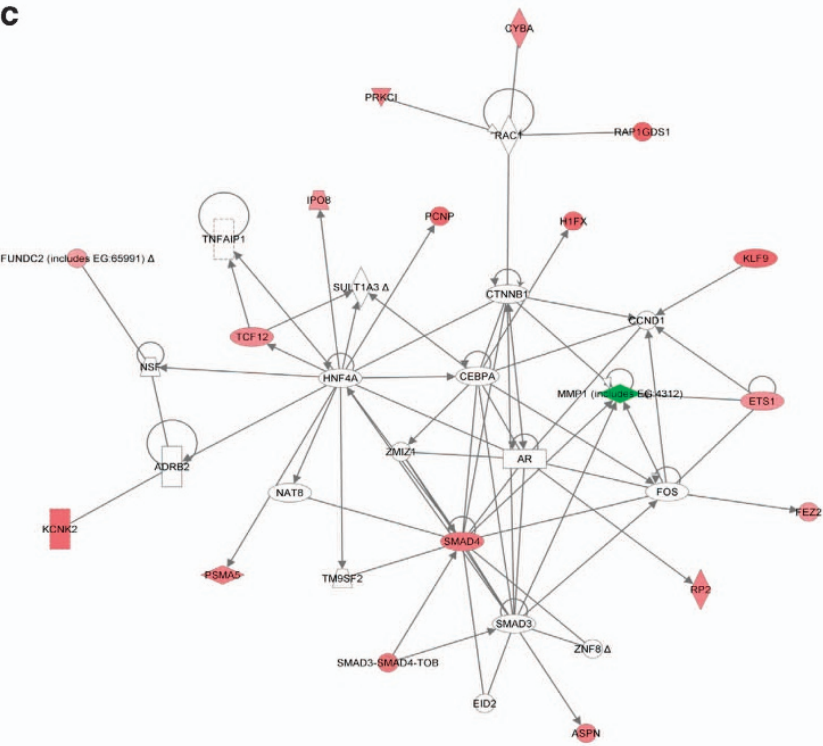

\begin{tabular}{|c|c|c|}
\hline Analysis category & p & Key genes related to functions \\
\hline Cell Death & $\begin{array}{l}\text { 4.95E- }-66 \text { to } \\
4.67 \mathrm{E}-02\end{array}$ & $\begin{array}{l}\text { ETSI, SNDI, F2R, TRIM28, DEGSI, TCFI2, SHCI, ZMAT3, PRKCI, } \\
\text { CYBA, GNB2, ITGAV, SMAD4, , null, GPX4, POLK, MMPI, MCLI, } \\
\text { RBBP4 }\end{array}$ \\
\hline $\begin{array}{l}\text { Cellular Growth and } \\
\text { Proliferation }\end{array}$ & $\begin{array}{l}1.78 \mathrm{E}-04 \\
\text { to4.67E--02 }\end{array}$ & $\begin{array}{l}\text { ETSI, DLGI, SNDI, F2R, TRIM28, KCNK2, CNOT8, DEGSI, TCFI2, } \\
\text { KLF9, SHCI, ZMAT3, PRKCI, ITGAV, SMAD4, null, GPX4, MCLI, } \\
\text { RBBP4 }\end{array}$ \\
\hline Cell Morphology & $\begin{array}{l}4.44 \mathrm{E}-04 \text { to } \\
4.92 \mathrm{E}-02\end{array}$ & $\begin{array}{l}\text { ETSI, SHCl, DLGI, PRKCI, F2R, ASPN, ITGAV, SMADA, null, POLK, } \\
R B B P 4\end{array}$ \\
\hline $\begin{array}{l}\text { Cellular Assembly and } \\
\text { Organisation }\end{array}$ & $\begin{array}{l}7.01 E-04 \text { to } \\
4.41 \mathrm{E}-02\end{array}$ & $\begin{array}{l}\text { ETSI, DLGI, ACTR2, F2R, ARPCIB, SHCI, KLFY, PRKCI, ITGAV, } \\
\text { SMADA, GPXA, MCLI, RBBPA }\end{array}$ \\
\hline Cellular Development & $\begin{array}{l}7.01 \mathrm{E}-04 \text { to } \\
4.92 \mathrm{E}-02\end{array}$ & $\begin{array}{l}\text { ETSI, DLGI, SNDI, F2R, DEGSI, TCFI2, SHCI, KLF9, PRKCI, } \\
\text { ITGAV, ASPN, SMAD4, null, MMPI, MCLI }\end{array}$ \\
\hline Tissue Development & $\begin{array}{l}8.02 \mathrm{E}-04 \mathrm{to} \\
4.41 \mathrm{E}-02\end{array}$ & ETSI, DLGI, SHCI, F2R, ITGAV, SMAD4, MMPI, TCFI2 \\
\hline $\begin{array}{l}\text { Free Radical } \\
\text { Scavenging }\end{array}$ & $\begin{array}{l}1.62 \mathrm{E}-03 \text { to } \\
3.13 \mathrm{E}-02\end{array}$ & ETSI, F2R, CYBA \\
\hline Cellular Compromise & $\begin{array}{l}1.82 \mathrm{E}-03 \text { to } \\
2.62 \mathrm{E}-02\end{array}$ & SHCI, PRKCI, ITGAV \\
\hline $\begin{array}{l}\text { Inflammatory } \\
\text { Response }\end{array}$ & $\begin{array}{l}2.33 \mathrm{E}-03 \text { to } \\
4.92 \mathrm{E}-02\end{array}$ & ETSI, SHCI, F2R, ITGAV, GPX4, MMPI \\
\hline Cell Cycle & $\begin{array}{l}2.65 \mathrm{E}-03 \text { to } \\
4.54 \mathrm{E}-02\end{array}$ & ETSI, SHCI, KLF9, DLGI, ITGAV, SMAD4, null, POLK, DEGSI \\
\hline $\begin{array}{l}\text { Skeletal and Muscular } \\
\text { System Development } \\
\text { and Function }\end{array}$ & $\begin{array}{l}2.65 \mathrm{E}-03 \text { to } \\
4.16 \mathrm{E}-02\end{array}$ & ETSI, DLGI, SHCI, ASPN, ITGAV, MMPI, TCFI2 \\
\hline Cell Signalling & $\begin{array}{l}7.85 \mathrm{E}-03 \text { to } \\
4.14 \mathrm{E}-02\end{array}$ & SHCl, KLFY, F2R, ITGAV, SMAD4, MMPI, MCLI \\
\hline
\end{tabular}

d

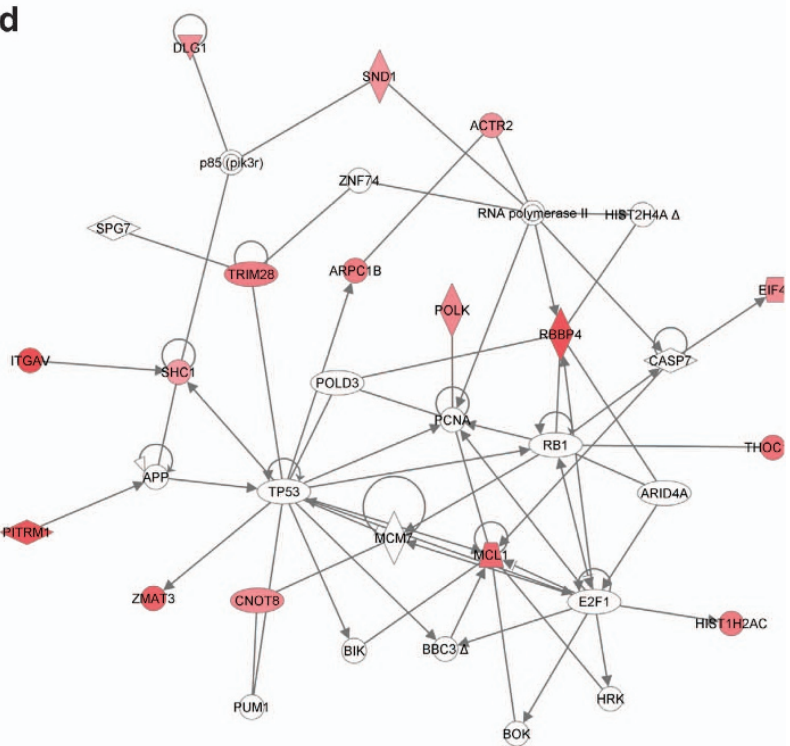

e

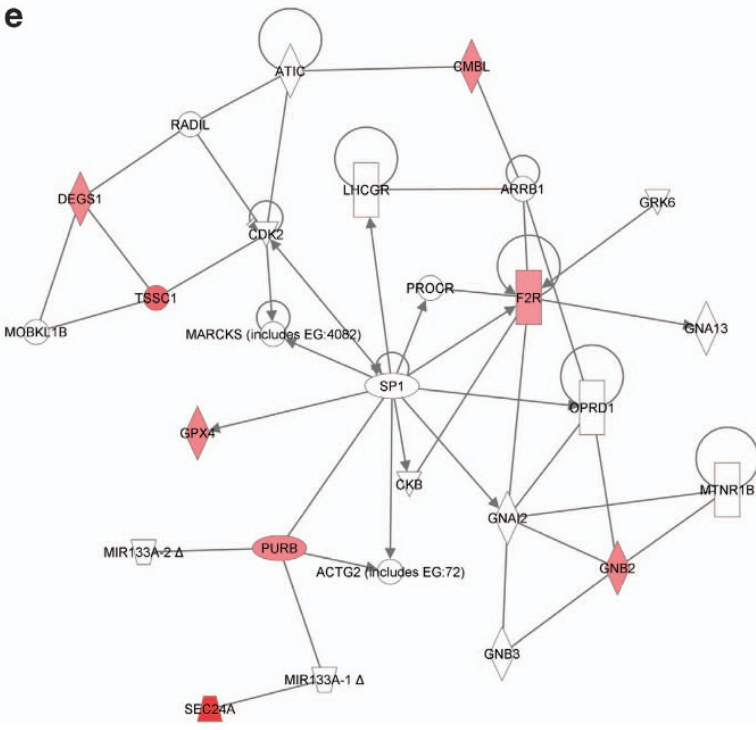


Figure 6 Functional analysis of the $0 \mathrm{~h}$ data set of genes with IPA software. (a and $\mathbf{b})$ Key biological functions associated with genes that were selectively upregulated $(n=52)$ and downregulated $(n=1)$ in aged SCs versus young SCs before in vitro culture $(0 \mathrm{~h})$. The analysis revealed that the top function involved is represented by cell death. (c-e) The three top networks generated by the IPA software, showing genes selectively dysregulated in the proliferating SCs at $0 \mathrm{~h}$, as shown in $\mathbf{a}$ and $\mathbf{b}$ (score range, 15-38). Genes in red show increased expression in aged SCs, whereas genes in green show decreased expression in aged SCs, when compared with young SCs. Genes in white represent the transcripts not modulated under the different conditions. Arrows indicate that a molecule acts on another, whereas lines indicate that a molecule binds to another. The gene networks show the nodes of genes involved in cell death (SMAD4, MMP1) (c), in cell death (MCL1), actin stress fibre formation (RBBP4, ITGAV), and muscle development and morphogenesis (DLG1, SHC1) (d), and in apoptotic pathways (F2R, GNB2, DEGS1) (e)

To assess myogenin and cleaved caspase-3 expression, the SCs were stained through a double indirect fluorescence procedure, as above, using a mouse antimyogenin monoclonal antibody (Santa Cruz Biotechnology, Santa Cruz, CA, USA) and a rabbit anti-cleaved caspase-3 antibody (Cell Signaling), diluted at 1:50 and $1: 100$, respectively, in $1 \% \mathrm{BSA} / \mathrm{DPBS}$, for $45 \mathrm{~min}$ at $\mathrm{RT}$.

Real-time PCR. Myoblasts were maintained for about $16 \mathrm{~h}$ in growth medium. RT-PCR was performed at $4,24,48$, and $72 \mathrm{~h}$ in the presence of growth medium. Total RNA was purified using the standard TRIzol protocol (Sigma-Aldrich, Milan, Italy). A small aliquot of RNA was used for spectrophotometric quantification and quality control using electrophoresis separation. Gene expression data were obtained using TaqMan low density array (Applied Biosystems-MDS Sciex, Toronto, ON, Canada). cDNA was generated with High Capacity cDNA Reverse Transcription kits (Applied Biosystems), according to the manufacturer's protocol, starting from $1 \mu \mathrm{g}$ RNA per sample. One hundred nanograms $(2 \mu \mathrm{l}) \mathrm{cDNA}$ was used in each sample. Then, $48 \mu \mathrm{l}$ nuclease-free water and $50 \mu \mathrm{l} 2 \times$ TaqMan Universal PCR Master Mix (Applied Biosystems) were added for the real-time PCR measurements. This mixture was divided over sample-loading ports of the TaqMan low density arrays. The arrays were centrifuged twice $(2 \mathrm{~min}, 331 \times g$ at RT). Subsequently, the card was sealed. RT-PCR amplification was performed using an Applied Biosystems Prism 7900HT Sequence Detection System, connected to the Sequence Detector Software (SDS version 2.0; Applied Biosystems) for data collection and analysis. The relative quantification of target gene expression was evaluated with the data from the SDS software, using the arithmetical formula $2^{-\mathrm{DDCt}}$, according to the comparative $\mathrm{Ct}$ method, which represented the amount of the target normalised to the endogenous control (GAPDH).

Transcriptome analysis. Gene expression profile analysis was performed using the SC populations isolated from the muscle fragments obtained from the vastus lateralis biopsies of healthy young and old subjects and cultured in growth medium. The human oligonucleotide set consists of 21329 70-mer sequences (Operon version 2.0, Cologne, Germany) designed on the Human Unigene clusters, mainly in the $3^{\prime}$-terminal region. The individual genes analysed via the microarrays were 10664 . Each oligonucleotide was spotted in two replicates on the MICROMAX SuperChip I glass slide (PerkinEImer Life Sciences Inc., Waltham, MA, USA) using a Biorobotics Microgrid II robotic station fitted with splitpin (M-medical, Milan, Italy). Details of the slide design and sequence selection are presented on the manufacturer's website (http://www.microcribi.cribi.unipd.it/ e-index.htm).

Total RNA from the cultured human SCs was isolated using the NucleoSpin RNA II kits (Macherey-Nagel, Düren, Germany), according to the manufacturer's instructions. RNA 6000 LabChip kits were used with the Agilent 2100 bioanalyser (Agilent Technologies, Palo Alto, CA, USA), to determine the integrity of the RNA samples obtained from the human SCs. On average, the ratio was 1.8. Aliquots of each RNA sample $(2 \mu \mathrm{g})$ were amplified and labelled using Amino Allyl MessageAmpTM aRNA amplification and labelling kits (Ambion, Austin, TX, USA).

For hybridisation, the labelled aaRNAs were combined with water and hybridisation buffer $(500 \mu \mathrm{l} 20 \times \mathrm{SSC}, 20 \mu \mathrm{l} 10 \%$ SDS, $100 \mu \mathrm{l} \mathrm{sSDNA}(2 \mu \mathrm{g} / \mu \mathrm{l})$, $500 \mu$ l formamide, $880 \mu$ l water) with stirring at $65^{\circ} \mathrm{C}$, to a total volume of $125 \mu \mathrm{l}$. Microarray hybridisation was performed on the ArrayBooster hybridisation station (Advaltix, Brunnthal, Germany) humidified with $250 \mu$ l hybridisation buffer. The hybridisation solution was sandwiched between the Adva-Card and the microarray. The hybridisation proceeded overnight at $48^{\circ} \mathrm{C}$. Two replicates of each experiment were analysed using different microarray slides in which the sample and reference RNAs labelled with either Cy3 or Cy5 fluorochromes were crossed for both of the combinations. Slides were washed in SSC buffer and $0.2 \%$ SDS for $4 \mathrm{~min}, 0.1 \times$ SSC, and $0.2 \%$ SDS for $4 \mathrm{~min}$, twice in $0.2 \times$ SSC for $4 \mathrm{~min}$, and finally twice in $0.1 \times$ SSC for $4 \mathrm{~min}$. Digital images were generated using a GSI Lumonics LITE dual confocal laser scanner (ScanArray Microarray Analysis System-Perkin Elmer). All of the spot signal intensities were collected manually using the QuantArray Analysis Software (GSI Lumonics, Ottawa, ON, Canada) and corrected for local backgrounds and arranged in an Excel file for further analysis. Normalised values were calculated for each spot, using the MIDAS software (TIGR Microarray Data Analysis System), which is available at http://www.tigr.org. The values were converted to a logarithmic scale. The final values corresponded to the $\log _{2}$ ratio of the normalised intensities (for example, $\log _{2} l_{\text {aged }} / l_{\text {young }}$ ), where positive numbers corresponded to RNA overexpressed in the aged SCs. Differentially expressed genes were detected with the SAM programme, which is available at http://wwwstat.stanford.edu/ tibs/SAM/index.html and were analysed through the IPA software. IPA predicts functional networks based on known protein-protein and functional interactions. IPA infers and ranks networks with a score, expressed as a numerical value, which is a probabilistic fit between the amount of focus genes that are potentially eligible for a network composition and present on a given gene list, the size of the network, and all of the molecules present in the Ingenuity Knowledge Base that might be part of such a network.

Statistical analysis. All quantitative data are reported as means \pm S.E. or \pm S.D. Statistical analyses were performed using one-way ANOVA or Student $t$-tests. Values of $P<0.05$ were considered statistically significant.

\section{Conflict of Interest}

The authors declare no conflicts of interest.

Acknowledgements. We thank Dr. Gianna Impicciatore for skilful assistance in manuscript preparation. This study was supported by funds from the Italian Ministry of University and Research, granted in 2011 to Professor Roberta Di Pietro and Professor Stefania Fulle, and by the Carichieti Foundation, Chieti, Italy.

1. Brack AS, Conboy MJ, Roy S, Lee M, Kuo CJ, Keller C et al. Increased Wnt signaling during aging alters muscle stem cell fate and increases fibrosis. Science 2007; 317 : 807-810.

2. Lepper $\mathrm{C}$, Conway SJ, Fan CM. Adult satellite cells and embryonic muscle progenitors have distinct genetic requirements. Nature 2009; 460: 627-631.

3. Gopinath SD, Rando TA. Stem cell review series: aging of the skeletal muscle stem cell niche. Aging Cell 2008; 7: 590-598.

4. Mauro A, Adams WR. The structure of the sarcolemma of the frog skeletal muscle fiber. J Biophys Biochem Cytol 1961; 10: 177-185.

5. Relaix F, Rocancourt D, Mansouri A, Buckingham MA. Pax3/Pax7-dependent population of skeletal muscle progenitor cells. Nature 2005; 435: 948-953.

6. Grounds MD. Muscle regeneration: molecular aspects and therapeutic implications. Curr Opin Neurol 1999; 12: 535-543.

7. Snijders T, Verdijk LB, Beelen M, McKay BR, Parise G, Kadi F et al. A single bout of exercise activates skeletal muscle satellite cells during subsequent overnight recovery. Exp Physiol 2012; 97: 762-773.

8. Bischoff $R$. The satellite cell and muscle regeneration. In: Engel AG, Franzini-Armstrong $C$ (eds). Myology, Basic and Clinical. McGraw-Hill: New York, NY, USA, 1994. pp 97-118.

9. Carlson BM. Factors influencing the repair and adaptation of muscles in aged individuals: satellite cells and innervation. J Gerontol A Biol Sci Med Sci 1995; 50: 96-100.

10. Roth SM, Martel GF, Ivey FM, Lemmer JT, Metter EJ, Hurley BF et al. Skeletal muscle satellite cell populations in healthy young and older men and women. Anat Rec 2000; 260: 351-358.

11. Jejurikar SS, Henkelman EA, Cederna PS, Marcelo CL, Urbanchek MG, Kuzon WM Jr. Aging increases the susceptibility of skeletal muscle derived satellite cells to apoptosis. Exp Gerontol 2006; 41: 828-836.

12. Collins CA, Zammit PS, Ruiz AP, Morgan JE, Partridge TA. A population of myogenic stem cells that survives skeletal muscle aging. Stem Cells 2007; 25: 885-894. 
13. Jones DL. Aging and the germ line: where mortality and immortality meet. Stem Cell Rev 2007; 3: 192-200.

14. Rando TA. Stem cells, ageing and the quest for immortality. Nature 2006; 441: 1080-1086.

15. Fulle S, Centurione L, Mancinelli R, Sancilio S, Manzoli FA, Di Pietro R. Stem cell ageing and apoptosis. Curr Farm Des 2012; 18: 1694-1717.

16. Fulle S, Di Donna S, Puglielli C, Pietrangelo T, Beccafico S, Bellomo R et al. Age-dependent imbalance of the antioxidative system in human satellite cells. Exp Gerontol 2005; 40: 189-197.

17. Beccafico S, Puglielli C, Pietrangelo T, Bellomo R, Fanò G, Fulle S. Age-dependent effects on functional aspects in human satellite cells. Ann N Y Acad Sci 2007; 1100: 345-352.

18. Teixeira Vde O, Filippin LI, Xavier RM. Mechanisms of muscle wasting in sarcopenia. Rev Bras Reumatol 2012; 123: 252-259.

19. Lamkanfi M, Festjens N, Declercq W, Vanden Berghe T, Vandenabeele P. Caspases in cell survival, proliferation and differentiation. Cell Death Differ 2007; 14: 44-55.

20. Di Pietro R, Zauli G. Emerging non-apoptotic functions of tumor necrosis factor-related apoptosis-inducing ligand (TRAIL)/Apo2L. J Cell Physiol 2004; 201: 331-340.

21. Jackson MJ, McArdle A. Age-related changes in skeletal muscle reactive oxygen species generation and adaptive responses to reactive oxygen species. J Physiol 2011; 589: 2139-2145.

22. Wang J, Walsh K. Resistance to apoptosis conferred by Cdk inhibitors during myocyte differentiation. Science 1996; 273: 359.

23. Xiao R, Ferry AL, Dupont-Versteegden EE. Cell death-resistance of differentiated myotubes is associated with enhanced anti-apoptotic mechanisms compared to myoblasts. Apoptosis 2011; 16: 221-234.

24. Sandri M. Apoptotic signaling in skeletal muscle fibers during atrophy. Curr Opin Clin Nutr Metab Care 2002: 5: 249-253.

25. Dupont-Versteegden EE. Apoptosis in muscle atrophy: relevance to sarcopenia. Exp Gerontol 2005; 40: 473-481.

26. Fernando P, Kelly JF, Balazsi K, Slack RS, Megeney LA. Caspase 3 activity is required for skeletal muscle differentiation. Proc Natl Acad Sci USA 2002; 99: 11025-11030.

27. Murray TV, McMahon JM, Howley BA, Stanley A, Ritter T, Mohr A et al. A non-apoptotic role for caspase-9 in muscle differentiation. J Cell Sci 2008; 15: 3786-3793.

28. Shaltouki A, Freer M, Mei $Y$, Weyman CM. Increased expression of the pro-apoptotic $\mathrm{Bcl} 2$ family member PUMA is required for mitochondrial release of cytochrome $\mathrm{C}$ and the apoptosis associated with skeletal myoblast differentiation. Apoptosis 2007; 12: 2143-2154.

29. Fulle S, Protasi F, Di Tano G, Pietrangelo T, Beltramin A, Boncompagni S et al. The contribution of reactive oxygen species to sarcopenia and muscle ageing. Exp Gerontol 2004; 39: 17-24.

30. Minet AD, Gaster M. Cultured senescent myoblasts derived from human vastus lateralis exhibit normal mitochondrial ATP synthesis capacities with correlative concomitant ROS production while whole cell ATP production is decreased. Biogerontology 2012; 13: 277-285.

31. Banan A, Zhang LJ, Farhadi A, Fields JZ, Shaikh M, Forsyth CB et al. Critical role of the atypical $\{l a m b d a\}$ isoform of protein kinase $\mathrm{C}$ (PKC-\{lambda\}) in oxidant-induced disruption of the microtubule cytoskeleton and barrier function of intestinal epithelium. J Pharmacol Exp Ther 2005; 312: 458-471.
32. Zaccagnini G, Martelli F, Magenta A, Cencioni C, Fasanaro P, Nicoletti C et al. p66(ShcA) and oxidative stress modulate myogenic differentiation and skeletal muscle regeneration after hind limb ischemia. J Biol Chem 2007; 282: 31453-31459.

33. Howard PL, Chia MC, Del Rizzo S, Liu FF, Pawson T. Redirecting tyrosine kinase signaling to an apoptotic caspase pathway through chimeric adaptor proteins. Proc Natl Acad Sci USA 2003; 100: 11267-11272.

34. Ramachandra M, Atencio I, Rahman A, Vaillancourt M, Zou A, Avanzini J et al. Restoration of transforming growth factor Beta signaling by functional expression of smad4 induces anoikis. Cancer Res 2002; 62: 6045-6051.

35. Hu C, Zhang S, Gao X, Gao X, Xu X, Lv Y et al. Roles of Kruppel-associated BoX (KRAB)-associated Co-repressor KAP1 Ser-473 Phosphorylation in DNA damage response. J Biol Chem 2012; 287: 18937-18952.

36. Higashi Y, Asanuma M, Miyazaki I, Haque ME, Fujita N, Tanaka K et al. The p53-activated gene, PAG608, requires a zinc finger domain for nuclear localization and oxidative stress-induced apoptosis. J Biol Chem 2002; 277: 42224-42232.

37. Piret JP, Minet E, Cosse JP, Ninane N, Debacq C, Raes M et al. Hypoxia-inducible factor1-dependent overexpression of myeloid cell factor- 1 protects hypoxic cells against tertbutyl hydroperoxide-induced apoptosis. J Biol Chem 2005; 280: 9336-9344.

38. Nomura K, Imai H, Koumura T, Arai M, Nakagawa Y. Mitochondrial phospholipid hydroperoxide glutathione peroxidase suppresses apoptosis mediated by a mitochondrial death pathway. J Biol Chem 1999; 274: 29294-29302.

39. Pietrangelo T, D'Amelio L, Doria C, Mancinelli R, Fulle S, Fanò G. Tiny percutaneous needle biopsy: an efficient method for studying cellular and molecular aspects of skeletal muscle in humans. Int J Mol Med 2011; 27: 361-367.

40. Decary S, Mouly V, Hamida CB, Sautet A, Barbet JP, Butler-Browne GS. Replicative potential and telomere length in human skeletal muscle: implications for satellite cellmediated gene therapy. Hum Gene Ther 1997; 8: 1429-1438.

41. Fadok VA, Voelker DR, Campbell PA, Cohen JJ, Bratton DL, Henson PM. Exposure of phosphatidylserine on the surface of apoptotic lymphocytes triggers specific recognition and removal by macrophages. J Immunol 1992; 148: 2207-2216.

42. Caravatta L, Sancilio S, di Giacomo V, Rana R, Cataldi A, Di Pietro R. PI3-K/Aktdependent activation of CAMP-response element-binding (CREB) protein in Jurkat leukemia cells treated with TRAIL. J Cell Physiol 2008; 214: 192-200.

43. Giampietro F, Sancilio S, Tiboni GM, Rana RA, Di Pietro R. Levels of apoptosis in human granulosa cells seem to be comparable after therapy with a gonadotropin-releasing hormone agonist or antagonist. Fertil Steril 2006; 85: 412-419.

44. Ansari B, Coates PJ, Greenstein BD, Hall PA. In situ end-labelling detects DNA strand breaks in apoptosis and other physiological and pathological states. J Pathol 1993; 170: 1-8.

45. Ekert PG, Silke J, Vaux DL. Caspase inhibitors. Cell Death Differ 1999; 6: 1081-1086.

(c) (i) $\Theta($ Cell Death and Disease is an open-access journal Co published by Nature Publishing Group. This work is licensed under a Creative Commons Attribution-NonCommercialNoDerivs 3.0 Unported License. To view a copy of this license, visit http://creativecommons.org/licenses/by-nc-nd/3.0/ 